\title{
Effect of Different Host on Quantitative and Qualitative Soluble Protein of $\mathrm{H}$. armigera
}

\author{
Prerna B. Chikte ${ }^{1 *}$, Makarand P. Shinde ${ }^{1}$ and Manjusha S. Gaikwad ${ }^{2}$ \\ ${ }^{1}$ Agriculture Technology Information Centre, Dr. PDKV, Akola, India \\ ${ }^{2}$ College of Agriculture, Dr. PDKV, Akola, India \\ *Corresponding author
}

\section{Keywords}

H. armigera, Whole body Homogenate (WBH), Isoform,

Supernatent,

Electophoretogram,

Dr. Panjabrao

Deshmukh Krishi

Vidyapeeth

Article Info

Accepted:

18 January 2019

Available Online:

10 February 2019
An insight to biochemical nature of target pest, $H$. armigera is a prerequisite for an effective management system using natural product, especially against a pest with a wide host range. The present investigation carried out in laboratory to assess the influence of different host on qualitative and quantitative protein of $H$. armigera, revealed that the host pigeon pea has been the most suitable one for growth and development test insect, followed by artificial diet, chick pea and the least preferred being cotton. Considering soluble protein content in insect was variable in different tissues of $H$. armigera, samples were taken from whole body homogenate, haemolymph and midgut. The maximum induction of gut protein was observed in pigeon pea reared $H$. armigera, found to be a good inducer of protein having as well as the higher bands in haemolymph as compare to other, whereas cotton showed weak impression of protein.

\section{Introduction}

$H$. armigera (Hubner) is one of the most dominant insect in agriculture, Puri $1995^{[1]}$. Raheja, $1996^{[2]}$ reported that the problem of pests magnified due to its attack fruiting structure voracious feeding habits, high mobility and fecundity, multivoltine, overlapping generation with facultative diapause, nocturnal behaviour, migration host selection and propensity for acquiring resistance against wide range of insecticides besides being active round the year depending upon the season and food plants.

It has been observed that the type of food, the insect feeds upon affects the growth, development and reproduction of insects. The biological attributes of $H$. armigera on several hosts including pigeon pea, maize, sorghum, cotton, chick pea, safflower and many other host plants have been studied by Bhagat and Bhalani, $1994^{[3]}$; Sujalata Devi and Singh, $2004^{[4]}$. Amar and Sayed (2014) ${ }^{[5]}$ studied the 
effect of different host plants and artificial diet on growth and development of $H$. armigera. The developmental periods of the larvae were found shortest on pea and artificial diet and longest on cotton seed extensively support the present study.

Bilpate in $1989^{[6]}$ reported that the food plant significantly affect the growth, survival and reproduction of $H$. armigera. The larval development was found to be fast on maize and slowest on cotton. It has been reported that, the pest population or even individuals within the population have often possessed distinctive properties with respect to crop hosts. Claridge in $1989^{[7]}$ reported that this system solely depends on the understanding of interaction between pest population and their hosts.

Until 1980's the control of pests dependent on the broad spectrum chemicals and hence it was not required to analyse the variation within and between pest population. However, an early development of resistance to chemical pesticides has forced to applied biologist to understand the nature and evaluation of such phenomenon. These investigation planned to study the biochemical analysis in terms of protein content of $H$. armigera showing different expression in the insect reared on different hosts can found useful in induction of immunity in the plants as well as in suppression of pest programme.

\section{Materials and Methods}

The present work was carried out in laboratory of the Department of Entomology, Dr. Panjabrao Deshmukh Krishi Vidyapeeth, Akola. The rearing of $H$. armigera was undertaken in laboratory at $27 \pm 2^{0} \mathrm{C}$ and relative humidity $72 \pm 2$ per cent. The $\mathrm{F}_{3}$ generation population of test insect used for present investigation were fed with pigeon pea, chick pea, artificial diet and cotton. The estimation of soluble protein was done from whole body homogenate, mid gut, haemolymph in the insect reared on different host by Bradford ${ }^{[7]}$.

The third instar larvae were separated and starved for 7-8 Hrs. to remove all digested food particles. The whole larvae and gut homogenised separately using Sodium Phosphate buffer.

The WBH and gut obtained was centrifuged at $10000 \mathrm{RPM}$ for 15 minutes at $4^{0} \mathrm{C}$. The debris and cellular matter discarded and supernatant obtained was stored at $-20^{\circ} \mathrm{C}$ and used as protein source for electrophoresis.

For quantitative estimation of protein $5 \mathrm{ml}$ of sample added in the well of microplate. Then $0.15 \mathrm{~N} \mathrm{NaCl}$ solution were added in this wells and $200 \mathrm{ml}$ of Bradford reagent loaded in each well and incubation was carried out for 15 min. at room temperature. Absorbance was read in microplate reader equipped with 600 nm. Concentration of protein from haemolymph, gut and whole body homogenate from larvae reared on different food substrate was determined from standard curve. Each sample was measured in triplicate to minimize error.

\section{Results and Discussion}

\section{Effect of different host on quantitative soluble protein of $\boldsymbol{H}$. armigera}

The protein plays the significant role in compensatory mechanism of insect during growth and toxic stress. The haemolymph, WBH and midgut have been chosen for the study. Midgut was taken in the study, as one of the major tissues for synthesis of various biochemical constituents. WBH represent all tissues together and reflects changes at nutrient uptake and haemolymph acts as a 
medium for interchange of metabolite with the corresponding influence of midgut. The data depicted in Table 1 reveal the variation in the protein content in the different parts of $H$. armigera reared on different hosts. The higher protein content was observed in $H$. armigera reared on pigeon pea by recording $0.538 \mu \mathrm{g} / \mathrm{ml}$ protein in the gut, while 1.95 $\mu \mathrm{g} / \mathrm{ml}$ protein was observed in the $\mathrm{WBH}$ and $2.50 \mu \mathrm{g} / \mathrm{ml}$ protein content in the haemolymph.

The next high protein content was noted in the larvae of $H$. armigera reared on artificial diet with $0.46 \mu \mathrm{g} / \mathrm{ml}$ protein in gut, 2.25 $\mu \mathrm{g} / \mathrm{ml}$ in $\mathrm{WBH}$ and $2.84 \mu \mathrm{g} / \mathrm{ml}$ in haemolymph. The protein content in chick pea reared larvae of $H$. armigera was at par with the protein content of $H$. armigera larvae reared on artificial diet, it noted $0.275 \mu \mathrm{g} / \mathrm{ml}$ protein content in gut, 2.36 and $2.49 \mu \mathrm{g} / \mathrm{ml}$ in $\mathrm{WBH}$ and the haemolymph respectively.

The least protein content was found in the insect reared on host cotton that was recorded as $0.177 \mu \mathrm{g} / \mathrm{ml}$ from gut, $0.855 \mu \mathrm{g} / \mathrm{ml}$ from $\mathrm{WBH}$ and $1.86 \mu \mathrm{g} / \mathrm{ml}$ from haemolymph.

In comparison to gut and $\mathrm{WBH}$, the high protein content was found in haemolymph ranging from $1.86-2.84 \mu \mathrm{g} / \mathrm{ml}$. The highest protein content was noted in haemolymph of insect reared on artificial diet i.e. $2.84 \mu \mathrm{g} / \mathrm{ml}$, which was followed by the insect reared on the host of pigeon pea $(2.50 \mu \mathrm{g} / \mathrm{ml})$ and chick pea $(2.49 \mu \mathrm{g} / \mathrm{ml})$, the least protein content $(1.86 \mu \mathrm{g} / \mathrm{ml})$ was observed in the insect reared on cotton.

The $H$. armigera reared on different food substrate i.e. cotton, pigeon pea, chick pea and artificial diet and also recorded the higher protein content in the WBH next to haemolymph. Amongst the different hosts, the highest value was noted in the insect reared on chick pea $(2.36 \mu \mathrm{g} / \mathrm{ml})$, followed by the artificial diet $(2.25 \mu \mathrm{g} / \mathrm{ml})$ and pigeon pea $(1.95 \mu \mathrm{g} / \mathrm{ml})$. The least protein content $(0.855$ $\mu \mathrm{g} / \mathrm{ml}$ ) was found in the WBH of the insect reared on cotton.

The protein content was found in the gut of larvae as compare to the $\mathrm{WBH}$ and haemolymph. The insect develop on the host of pigeon pea had $(0.538 \mu \mathrm{g} / \mathrm{ml})$ protein gut followed by the artificial diet $(0.460 \mu \mathrm{g} / \mathrm{ml})$ and chick pea $(0.275 \mu \mathrm{g} / \mathrm{ml})$ being the least protein the gut of $H$. armigera $(0.177 \mu \mathrm{g} / \mathrm{ml})$ reared on the host of cotton.

The above results indicate that the insect $H$. armigera develop on different host to have a variable quantity of protein in different tissues depending on the host. The insect reared on pigeon pea has highest soluble protein content in the gut as compare to other host. Whereas, the higher amount of soluble protein was observed in WBH of insect reared on chick pea and highest content of protein in haemolymph in insect reared on artificial diet. However, the lowest protein was observed in the insect develop on cotton irrespective of the tissues.

Such kind of observation in respect of biology of the insect was also reported by $\mathrm{Wu}$ and $\mathrm{Li}^{[9]}$ revealing that 7 to 13 per cent increase in protein in the insect diet of $H$. armigera was shorten larval period and enhance the adult fecundity. Similar results reported by Malarvannan and Subashini ${ }^{[9]}$, who have recorded the high content of total soluble protein in pigeon pea reared on $H$. armigera (0.62). Larvae followed by chickpea reared larvae (0.57), which corroborate the present finding.

\section{Effect of different hosts on qualitative soluble protein of $\boldsymbol{H}$. armigera}

The electrophoretic banding patterns of soluble protein of gut, WBH and haemolymph 
protein in $H$. armigera reared on different food substrate were studied on $10 \%$ SDS PAGE, results are summarised in Table 2 and Figure 1 along with their molecular weight and RF values under notation of isoform P1 to P7 (Plate 1).

The more number of bands were present in haemolymph as compare to the midgut and $\mathrm{WBH}$ in the insect. Furthermore, the highest number of bands found in the haemolymph of insect reared on artificial diet and pigeon pea ranging the molecular weight from 278.00 $\mathrm{KDa}(\mathrm{P} 1)$ to $40.74 \mathrm{KDa}(\mathrm{P} 7)$.

Among this protein only one possesses the dark intensity (P4), four were found to possess light intensity (P1, P2, P6 and P7) and the only one protein band (P3) showed medium intensity. The next higher number of bands were detected in the chick pea developed insect which having P1, P2, P3, P4 and P6 bands amongst these three bands possessed light intensity while another two P3 and $\mathrm{P} 4$ possessed medium intensity. While, the least protein expression was seen in the haemolymph of insect reared on cotton that possessed only three bands amongst these, two were medium intense (P3 and P4) and one were light (P6).

The soluble protein extraction done from WBH of the $H$. armigera larvae reared on different hosts were found less as compared to protein extraction done from haemolymph from different insect of $H$. armigera. Only one medium intense bands (P4) was observed among all the insects except chick pea which possessed dark band.

The midgut showed low titre protein than haemolymph and WBH in which pigeon pea and cotton possessed two light bands (P4 and P5) while chick pea and artificial diet possessed one light band (P4).

During present investigation, it has been observed that pigeon pea is a good inducer of protein, which expressed six bands of 40.74 to $278 \mathrm{KDa}$ in haemolymph of H. armigera and two bands of $68.72,72.19 \mathrm{KDa}$ in midgut, followed by artificial diet and chickpea. While insect reared on cotton showed weak expression of protein as compared to all other insects.

The results obtained during present investigation indicate that the pigeon pea recorded the highest number of bands followed by artificial diet, chick pea and cotton.

The insect reared on cotton showed very weak expression of protein showing low protein bands in all the tissues, as compared to chick pea and artificial diet. Malavarnnan and Subashini ${ }^{[10]}$ reported similar kind of banding pattern of protein in the insect developed on pigeon pea, chick pea, cotton that supports the present findings.

Table.1 Quantitative protein estimation from H. armigera reared on different hosts $(\mu \mathrm{g} / \mathrm{ml})$

\begin{tabular}{|l|l|l|l|l|}
\hline Sr No & $\begin{array}{l}\text { Strain } \\
\text { (Mean } \pm \text { SD) }\end{array}$ & $\begin{array}{l}\text { Gut } \\
\text { (Mean } \pm \text { SD) }\end{array}$ & $\begin{array}{l}\text { WBH } \\
(\text { Mean } \pm \text { SD) }\end{array}$ & $\begin{array}{l}\text { Haemolymph } \\
(\text { Mean } \pm \text { SD) }\end{array}$ \\
\hline $\mathbf{1}$ & Cotton & $0.1770 \pm .03$ & $0.855 \pm 0.06$ & $1.86 \pm 0.032$ \\
\hline $\mathbf{2}$ & Pigeon pea & $0.538 \pm 0.04$ & $1.95 \pm 0.051$ & $2.50 \pm 0.025$ \\
\hline $\mathbf{3}$ & Chickpea & $0.275 \pm 0.06$ & $2.36 \pm 0.097$ & $2.449 \pm 0.015$ \\
\hline $\mathbf{4}$ & Artificial diet & $0.460 \pm 0.048$ & $2.25 \pm 0.058$ & $2.84 \pm 0.048$ \\
\hline
\end{tabular}

(All the figures are triplicate mean $+_{-}$SD) 


\section{Int.J.Curr.Microbiol.App.Sci (2019) 8(2): 2495-2501}

Table.2 Electophoretogram of soluble protein from H. armigera larvae reared on different hosts

\begin{tabular}{|c|c|c|c|c|c|c|c|c|c|c|c|c|c|c|}
\hline \multirow[t]{2}{*}{ Isoform } & \multicolumn{2}{|c|}{ Isoform/bands } & \multicolumn{4}{|c|}{ Midgut } & \multicolumn{4}{|c|}{ Whole body homogenate } & \multicolumn{4}{|c|}{ Chickpea } \\
\hline & $\begin{array}{c}\text { Mol Wt. } \\
\text { (KDa) }\end{array}$ & $\begin{array}{c}\text { RF } \\
\text { Value }\end{array}$ & Cotton & $\begin{array}{c}\text { Chick } \\
\text { pea }\end{array}$ & $\begin{array}{c}\text { Pigeon } \\
\text { pea }\end{array}$ & $\begin{array}{l}\text { Art. } \\
\text { diet }\end{array}$ & Cotton & $\begin{array}{c}\text { Chick } \\
\text { pea }\end{array}$ & $\begin{array}{c}\text { Pigeon } \\
\text { pea }\end{array}$ & $\begin{array}{l}\text { Art. } \\
\text { diet }\end{array}$ & Cotton & $\begin{array}{c}\text { Chick } \\
\text { pea }\end{array}$ & $\begin{array}{c}\text { Pigeon } \\
\text { pea }\end{array}$ & $\begin{array}{l}\text { Art. } \\
\text { diet }\end{array}$ \\
\hline $\mathrm{P}_{1}$ & 278.0 & 0.009 & - & - & - & - & - & - & - & - & - & $+(\mathrm{L})$ & $+(\mathrm{L})$ & $+(\mathrm{L})$ \\
\hline $\mathrm{P}_{2}$ & 217.0 & 0.027 & - & - & - & - & - & - & - & - & - & $+(\mathrm{L})$ & $+(\mathrm{L})$ & $+(\mathrm{L})$ \\
\hline $\mathrm{P}_{3}$ & 148.0 & 0.056 & - & - & - & - & - & - & - & - & $+(\mathrm{M})$ & $+(\mathrm{M})$ & $+(\mathrm{M})$ & $+(\mathrm{M})$ \\
\hline $\mathrm{P}_{4}$ & 72.19 & 0.118 & $+(\mathrm{L})$ & $+(\mathrm{L})$ & $+(\mathrm{L})$ & $+(\mathrm{L})$ & $+(\mathrm{L})$ & $+(\mathrm{D})$ & $+(\mathrm{L})$ & $+(\mathrm{L})$ & $+(\mathrm{M})$ & $+(\mathrm{M})$ & $+(\mathrm{D})$ & $+(\mathrm{D})$ \\
\hline $\mathrm{P}_{5}$ & 68.72 & 0.135 & $+(\mathrm{L})$ & - & $+(\mathrm{L})$ & - & - & - & - & - & - & - & - & - \\
\hline $\mathrm{P}_{1}$ & 40.74 & 0.315 & - & - & - & - & - & - & - & - & - & - & $+(\mathrm{L})$ & $+(\mathrm{L})$ \\
\hline Total & & & 2 & 1 & 2 & 1 & 1 & 1 & 1 & 1 & 3 & 5 & 6 & 6 \\
\hline
\end{tabular}


Fig.1 Electophoretogram of soluble protein from $H$. armigera larvae reared on different hosts

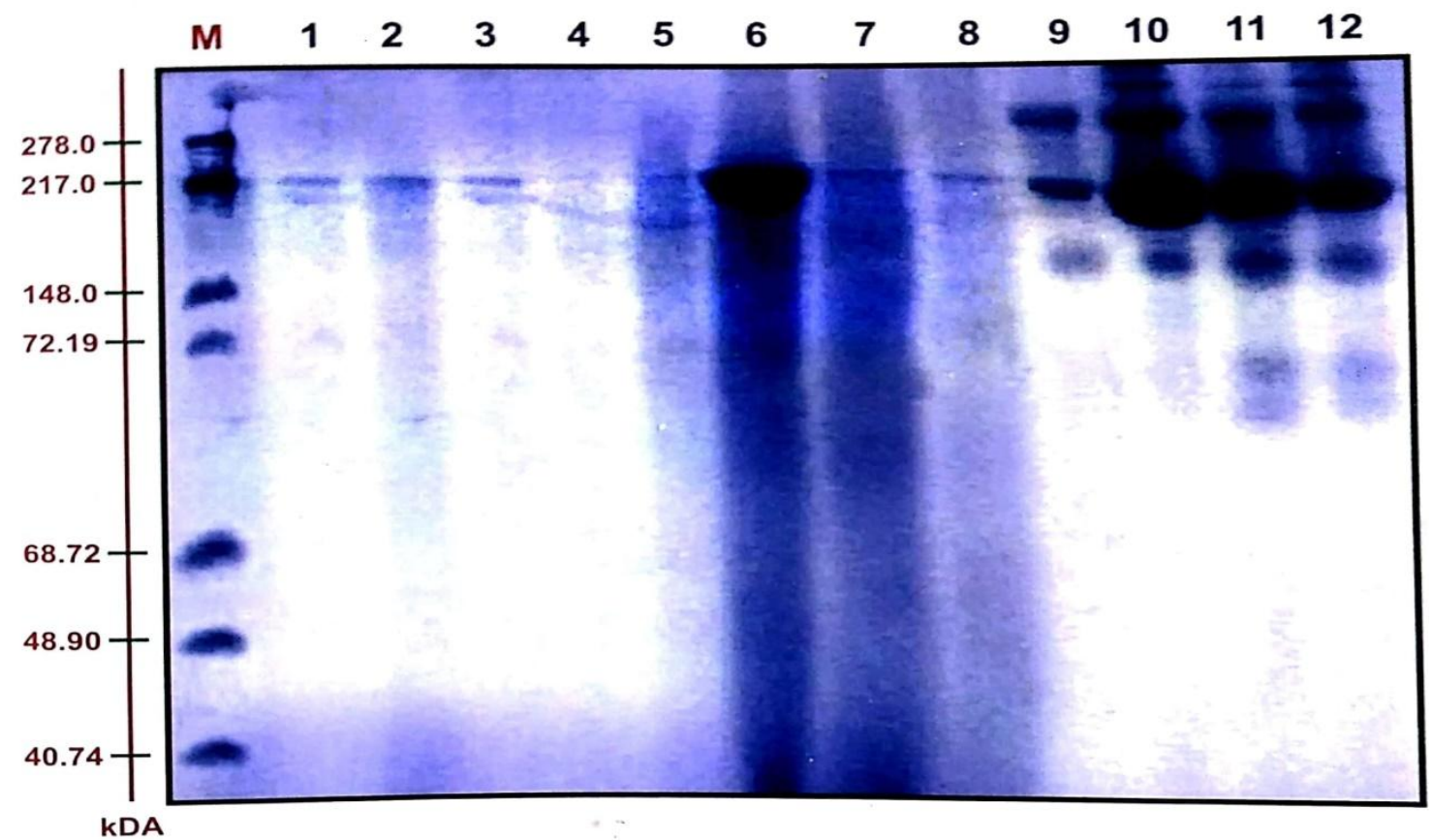

Legends:

M - Standard Molecular Weight Marker

1 - Mid gut Sample (Cotton)

2 - Mid gut Sample (Chick pea)

3 - Mid gut Sample (Pigeon pea)

4 - Mid gut Sample (Artificial diet)

5 - WBH Sample (Cotton)

Summary and conclusion of the study are as follows

The present investigation has revealed that the $H$. armigera being a polyphagus insect pest, had a different life span and also available genetic potential which can influence the overall insect pest status of insect not only on crop per se but also in ecosystem. The biochemical analysis in terms of protein content showing different expression in the insect reared on different host can found usefull in induction of immunity in plants as well as in suppression of pest programme. $H$. armigera influenced by the various hosts summarized that the protein content was variable in different tissues of $H$. armigera reared on pigeon pea recorded $0.538(\mu \mathrm{g} / \mathrm{ml})$ protein in the gut, while $2.36(\mu \mathrm{g} / \mathrm{ml})$ of
6 - WBH Sample (Chick pea)

7 - WBH Sample (Pigeon pea)

8 - WBH Sample (Artificial diet)

9 - Haemolymph Sample (Cotton)

10 - Haemolymph Sample (Chick pea)

11 - Haemolymph Sample (Pigeon pea)

12 - Haemolymph Sample (Artificial diet)

protein was observed in WBH in chick pea reared larvae and $2.84(\mu \mathrm{g} / \mathrm{ml})$ protein content is noticed in the haemolymph of artificial diet.

In respect of qualitative expression of protein, pigeon pea is good inducer of protein, expressed six bands in haemolymph sample of $H$. armigera and two bands in mid gut followed by artificial diet and chick pea. While, the insect reared on cotton showed weak expression of protein as compared to all other hosts.

\section{References}

1. Puri, S.N. Present status of IPM in India: Proceeding of National Seminar on IPM on Agriculture, Nagpur, Maharashtra. December, 1995, 29-30. 
2. Raheja, A. K. IPM Research and Development in India: Progress and Priorities Lal. O.P. (Eds.) Recent advances in Indian Entomology, APC Publication Pvt. Ltd., New Delhi. 1996; 115-126.

3. Bhagat, S. R. and P. A. Bhalani. Effect of five leguminous host plants on the growth index of gram pod borer Helicoverpa armigera (Hub.). GAV Res. J. 1994; 20 (1): 183-184.

4. Sujalata Devi, N. G. and T. K. Singh. Effect of Different host plants on growth and development of Gram pod borer Helicoverpa armigera (Hub.) Indian J. Entomology. 2004; 66 (2): 114-118.

5. A.E.A. Amer and A.A.A. Ei Sayed. Effect of different host plants and artificial diet on Helicoverpa armigera (Hubner) (Lepidopetra: Noctuidae). Development and growth Index. Journal of Entomology, 11: 299 - 305.

6. Bilpate, G.G. Investigation of Heliothis armigera (Hub.) on Marathwada XIII. Growth and development in different host. J. Maharashtra Agril. University.
1989; 3(2):139.

7. Claridge, M. F. Electrophoresis in Agriculture pest research technique of evolutionary biology in Electrophoretic studies on Agricultural pest systematics Ass. (eds. H.D. Loxdateadn. J.D. Holeander) Claredron Press, Oxford. 1989; Spl. Vol. 39: 1-6.

8. Bradford, M. M. A rapid and sensitive method for quantification of microorganisms quantities of protein utilizing the principles of protein dye binding. Annal. Biochem. 1976; 72: 248.

9. Wu, K.J. and M.H. Li. Nutritional ecology of the cotton bollworm $H$. armigera. Life table of the population on artificial diet with different protein levels. J. Acta. Entomol. Sinica. 1993; 36(1): 21-28.

10. Malarvannan, S. and H.D. Subashini. Influence of various host plants on the biochemical profile of Helicoverpa armigera (Hub) (Noctuidae: Lepidoptera). 2007; 69(1): 1-6.

\section{How to cite this article:}

Prerna B. Chikte, Makarand P. Shinde and Manjusha S. Gaikwad. 2019. Effect of Different Host on Quantitative and Qualitative Soluble Protein of $H$. armigera. Int.J.Curr.Microbiol.App.Sci. 8(02): 2495-2501. doi: https://doi.org/10.20546/ijcmas.2019.802.290 